Tkachenko V. O., Head of Unit on Assessment Efficiency

of Regional Policy of the Directorate of Regional Policy

Ministry of Communities and Territories Development of Ukraine

ORCID: https://orcid.org/0000-0001-9011-3209

Kyiv, Ukraine

DOI: https://doi.org/10.30525/978-9934-26-064-3-24

\title{
EU CONTRIBUTION TO THE DEVELOPMENT OF THE STATE REGIONAL POLICY IN UKRAINE BASED ON THE IMPLEMENTATION OF THE EU STRATEGY FOR DANUBE REGION
}

This thesis will represent the outcomes of author's empirical research on the role of the European Union in the development and implementation of the state regional policy of Ukraine. The research is focused on the EU-policy tools and possibilities developed in the framework of the European Union Strategy for the Danube Region (EUSDR) and implemented in Ukraine over the last years since ratification of the EU Danube Transnational Programme (Interгеg V-B Danube-CCI2014TC16M6TN001) in 2018.

The narrative conclusions of the author's research tackle such issues as strategic planning of Ukraine's state regional policy and its integration with EU strategic framework on objectives level.

In addition, active participation of Ukraine in the EUSDR will improve understanding of how to use EU financial instruments in combination with national funds of the State Budget and especially State Found of Regional Development and local budgets. Combination of state and EU funds shall be an effective funding instrument for local communities of Ukraine after they successfully finished the process of amalgamation as a result of Local Elections in October 2020. Mostly, EUSDR projects are financed by different EU-funds depending on its objectives, actions and targets consistency with EU common cohesion policy provisions.

Let us review the history of Danube Strategy establishment at glance to understand its role and impact into Ukraine's state regional 
policy development. It is worth mentioning that the EU Commission established EUSDR in 2010, when the first release of the Strategy was addresses to the European Parliament, the Council, the European Economic and Social Committee and the Committee of the Regions.

As per mentioned above first release of the EUSDR, the whole Strategy may be described in two documents: a Communication from the European Commission to the other EU Institutions, and an accompanying Action Plan, which complements the Communication [1]. The Action Plan is one of the outputs of the Strategy approach. For almost ten years of the EUSDR existence, Action Plan still the main operational document of the Strategy's annual activities. Its aim is to go from "words to actions" by identifying the concrete priorities for the macro-region. Once an action or project is included in the Action Plan, it should be implemented by the countries and stakeholders concerned. Therefore, the projects are considered to be concrete, with a start and end date. Generally, EUSDR projects requires financing, a project leader and project partners. There are also requirements or the projects under the EUSDR to be illustrative and provide examples of types of projects or approaches to be more generally encouraged [1].

Experience elaborated in the last 10 years in the framework of the EUSDR is extremely useful for Ukraine taking into consideration Ukraine's constitutional objectives to join the EU [2]. Currently, the EUSDR is strategic framework for the area stretches from the Black Forest (Germany) to the Black Sea (Romania-Ukraine-Moldova) and is home to 115 million inhabitants as written on Strategy's official website.

Starting from 2021, EUSDR annual Action plan serves as a basis for the embedding of the EUSDR into EU programmes. It will be much helpful for Ukraine as a potential candidate for EU-membership especially with regards to the Cohesion policy programmes, other EU funding instruments, EU Cohesion Policy provisions, national, regional, and local funding opportunities.

For instance, European commonly used approach of embedding EUSDR objectives will enable use of the following funds: 
- cohesion policy programmes - i.e. national, regional, territorial programmes under the European Regional Development Fund (ERDF), European Social Fund (ESF), Cohesion Fund (CF), and the European Maritime and Fisheries Fund (EMFF), as regulated in the draft Common Provisions Regulation (CPR) of the UESDR;

- other EU funding instruments and programmes, like the Instrument for Pre-accession Assistance (IPA II/III), the European Neighbourhood Instrument (ENI)/ Neighbourhood, Development and International Cooperation Instrument (NDICI), Connecting Europe Facility (CEF), LIFE, Horizon Europe, etc.;

- national, regional, local funding of the Danube Region Strategy participating states [1].

In 2021, Ukraine will be able to use multi-source approach for funding programmes and projects for regional development under the Danube Transnational Programme [4]. Combination of co-financing policy programmes and projects from a different EU-founds and state, local budgets, as well as other sources is usual practice for all EU member-countries, but not widely used in Ukraine for implementation regional policy projects. Ukrainian Government should use the opportunity of participation in the EUSDR for gaining experience in policy planning with regard to the efficient use of different fund sources accessible for Ukraine under EU-funds, such as IPA II/III, ENI, NDICI, LIFE, Horizon Europe.

Ukraine's National Coordinator and Ukrainian Ministries as a priority area participants will became key actors when it comes to identifying strategic topics for embedding and cooperation with managing authorities of the EU. Additionally, engaging Ukraine into development of the whole scope of strategic objectives for Danube Region will assist the country to use common approach with EU member-states based on the project management planning cycle for regional policy $[5 ; 7]$.

Above mentioned conclusions and recommendations are of high value as Ukraine expressed its interest to take on the EUSDR Presidency for the year 2022 at the National Coordinator's meeting in Zagreb in November 2019. In January 2021, Ukrainian Government 
adopted official notification on the will of Ukraine to be a chair-country of EUSDR starting from November 2021 to November 2022 [6].

The importance of the EU contribution to the development of state regional policy in Ukraine based on EUSDR practices is explained by the fact that Ukraine may become the first non-EU country taking on the EUSDR Presidency, which could be considered as an important step for the Strategy in deepening the involvement of non-EU countries within the EUSDR.

\section{References:}

1. EUSDR Implementation reports. (2020, December 23). Retrieved February 10, 2021. Available at: from https://danube-region.eu/about/implementationreports

2. Constitution of Ukraine (in UKR). Retrieved February 10, 2021. Available at: https://zakon.rada.gov.ua/laws/show/254\%D0\%BA/96-\%D0\%B2\%D1\%80\#Text

3. Sychenko Victor, Marenichenko Valery (2019) State Management of Regional Development On The Basis Of European Standards. Public Administration and Regional Development, Petro Mohyla Black Sea National University, issue 4, pp. 441-463.

4. European Regional Development Policies: History and Current Issues, by Sandy Dall'Erba Department of Economics, CATT, University of Pau, Cedex, France, May 2003, available at: http://aei.pitt.edu/2030/1/dallerba2.pdf

5. Rethinking Regional Development Policy-making, OSCD policy report, 2018. Available at: https://www.oecd.org/regional/rethinking-regional-development-policymaking-9789264293014-en.htm

6. Regulation of the Cabinet of Ministers of Ukraine from 27 January 2021, No.72-p.

7. Harri Laihonen (2013) Managing regional development: a knowledge perspective by Antti Lönnqvist; International Journal of Knowledge-Based Development (IJKBD), vol. 4, no. 1.

8. Kifyak V.F. (2013) Cross-border cooperation in the context of regional development policy-making. Bulletin of the Trade and Economic Institute. Chernivtsi: CHTEI KNTU. 2013. Vol. II (50). Economic sciences. P.101-106. 